\title{
Evaluating Water Stability Indices from Water Treatment Plants in Baghdad City
}

\author{
Awatif S. Alsaqqar, Basim H. Khudair, Sura Kareem Ali \\ Department of Civil Engineering, College of Engineering, Baghdad University, Baghdad, Iraq

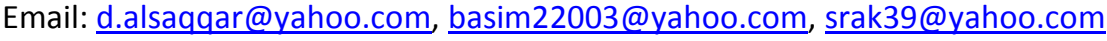

Received 7 August 2014; revised 2 September 2014; accepted 26 September 2014

Copyright (C) 2014 by authors and Scientific Research Publishing Inc.

This work is licensed under the Creative Commons Attribution International License (CC BY). http://creativecommons.org/licenses/by/4.0/

c) (i) Open Access

\section{Abstract}

Corrosion control is an important aspect of safe drinking water supplies. The effects of corrosion which may not be evident without monitoring are an important issue concerning both public health and economical aspects. Chemical stability parameters of water quality in water treatment plants in Baghdad city can improve drinking water quality. The treated water quality from water treatment plants in Baghdad city was investigated along the water flow path in this study. The water quality parameters related to chemical stability included temperature, alkalinity as $\mathrm{mg} / \mathrm{L} \mathrm{Ca-}$ $\mathrm{CO}_{3}$, calcium $\mathrm{mg} / \mathrm{L}$ as $\mathrm{Ca}, \mathrm{pH}$ and total dissolved solids (TDS) $\mathrm{mg} / \mathrm{L}$ for different samples from WTPs within Baghdad city were investigated. The two water quality indices, Langelier saturation index (LSI) and the Ryznar stability index (RSI), were calculated in order to evaluate the chemical stability of the drinking water samples. The results of LSI and RSI of the effluents from Baghdad's WTPs during 2000-2013 classified that corrosive water is produced and this indicates that the water is not safe for domestic use and will need the further treatment. The present study demonstrated the application of water stability indices in estimating/understanding the treated water chemical stability and appeared to be promising in the field of treated water quality management.

\section{Keywords}

Water Stability Indices, Chemical Stability, Langelier Index, Ryznar Index

\section{Introduction}

\subsection{Water Stability}

Stability of water is the tendency of water to either dissolve or deposit minerals varying with its chemical ma-

How to cite this paper: Alsaqqar, A.S., Khudair, B.H. and Ali, S.K. (2014) Evaluating Water Stability Indices from Water Treatment Plants in Baghdad City. Journal of Water Resource and Protection, 6, 1344-1351. 
keup. Water that tends to dissolve minerals is considered corrosive and that tends to deposit mineral is considered scaling. Corrosive water can dissolve minerals like calcium and magnesium, also can dissolve harmful metals such as lead and copper from plumbing utilities. Where scaling waters deposit a film of minerals on pipe walls and may prevents corrosion of metallic surfaces. If the scale deposition is too rapid, it also can be harmful and can damage appliances, such as water heaters, and increase pipe friction coefficients, in extreme cases, scale may clog pipes. Therefore, the most desirable water is one that is just slightly scaling [1].

Control of water quality in the distribution and plumbing systems seeks to preserve the basic characteristics of water during its conveyance from the point of production and treatment to the consumers tap. The finished water should be completely stable in its compositional and physical attributes. Also the conveyance system and accessory structures (pipelines, distributing reservoirs, mains and serves pipes) should be reactively inert to the water being conveyed. Most water quality parameters affect the corrosion process to some degree and that each pipe material is affected differently. Altering one parameter to subdue its effect on the corrosively of water may well change other water quality characteristics, perhaps rendering the water even more corrosive or less likely in some other way to meet drinking water standards [2]. At present, there is no requirement to produce water that is stable (either scale forming or corrosive) other than having a pH in the range 6.5 to 8.5 [3].

Water quality changes in drinking water distribution systems occur as a result of complex and often interrelated chemical and biological processes [4]. The chemical instability of water quality shows the occurrence of scale deposition and corrosion which can cause secondary pollution of water quality, increase energy consumption of water transportation and decrease service life of pipe networks [5].

Corrosive water is related to its $\mathrm{pH}$, alkalinity, hardness, temperature, dissolved oxygen, carbon dioxide, total dissolved solids and other physical, chemical and biological factors. Water with high levels of sodium, chloride, or other ions will increase the conductivity of the water causing corrosion and also be accelerated by high: flow rates within the piping system, water temperature, dissolved $\mathrm{O}_{2}$ and $\mathrm{CO}_{2}$ and dissolved salts such as sulfates [6].

\subsection{Water Stability Indices}

Although a number of indices have been developed, none has demonstrated the ability to accurately quantify and predict the corrosively or scaling of water. They can only give a probable indication. Experience has shown that if conditions encourage the formation of a protective calcium carbonate film, then corrosion will generally be minimized [7]. The most common methods used for calculating the stability of water are Langelier saturation index (LSI) and Ryznar stability index (RSI). LSI and RSI are designed to be predictive tools for calcium carbonate scale and they are not suitable for estimating calcium phosphate, calcium sulfate, silica or magnesium silicate scales [8]. Millete et al. [9] showed that almost 70\% of the representative utilities to have moderately to highly aggressive waters, where $16 \%$ - 18\% had highly aggressive waters and indicating aggressive to very aggressive waters as well as a comparison between the two indices showed good agreement in the results.

Pisigan and Singly [10] reported the influence of some water quality parameters in particular the LSI on the corrosion of galvanized steel using a dynamic circulating water system. Change in water quality parameter were monitored, hardness and alkalinity exhibited a continuous decline. Pisigan and Singly, [11] dictated from their experimental work that increasing the buffer capacity at a constant water alkalinity of $100 \mathrm{mg} / \mathrm{L}$ as $\mathrm{CaCO}_{3}$ in the $\mathrm{pH}$ range 6 - 9 decreased the corrosion rate of mild steel. However an increase in the buffer capacity at various $\mathrm{pH}$ by raising the alkalinity did not lower the corrosion rate because of the effects of higher ionic strength and conductivity. Also higher chloride content increased the corrosion rate in some waters of high buffer capacities. Steve et al. [12] evaluated the relationship between copper plumbing corrosion and variations in delivered water quality in several communities in the Pacific Northwest. Significant relationships were found for copper corrosion rate dependence on $\mathrm{pH}$ and free chlorine residual. The regression equation coefficient indicated that the corrosion rate changes with chlorine residual, approximately $25.6 \mu \mathrm{m} /$ year per $\mathrm{mg} / \mathrm{L}$ chlorine.

\subsection{Research Objective}

This paper is to evaluate the stability of the water flowing in the distribution systems in Baghdad city from the existing water treatment plants. Two indices may be calculated to assess the corrosively of water due to problems associated with calcium carbonate scale formation. Probably the best way to qualitatively predict the formation of $\mathrm{CaCO}_{3}$ scale is through the use of the Langelier Saturation Index (LSI) and the Ryznar Stability index 
(RSI). The calculation of these indices is through the investigation of the chemical stability parameters including Temperature, Alkalinity as $\mathrm{CaCO}_{3}$, Calcium as $\mathrm{Ca}$, $\mathrm{pH}$ and total dissolved solids (TDS) for the effluents from the WTPs within Baghdad city.

\section{Materials and Methods}

\subsection{Study Area Description}

Tigris river water is considered the only source of potable water for the city of Baghdad, and the river divides the city into right (Karkh) and left (Risafa) sides with a flow direction from north to south. The study area within Baghdad City is located in the Mesopotamian alluvial plain between latitudes $33^{\circ} 14^{\prime} \mathrm{N}-33^{\circ} 25^{\prime} \mathrm{N}$ and longitudes $44^{\circ} 31^{\prime} \mathrm{E}-44^{\circ} 17^{\prime} \mathrm{E}, 30.5$ to $34.85 \mathrm{~m}$ at sea level (a.s.l). The area is characterized by arid to semi-arid climate with dry hot summers and cold winters; the mean annual rainfall is about $151.8 \mathrm{~mm}$ [13]. In Baghdad city, a tremendous increase in freshwater demand is required due to the rapid growth in population and accelerated industrialization. The quality of the following water is affected by the pollution increase in the river stretch due to effluent discharges by various uncontrolled sources as domestic, industries, agriculture along the downstream stretch. Therefore treated water quality from WTPs monitoring is necessary to evaluate the treated water stability.

\subsection{Data Collection and Analysis}

All water treatment plants (WTPs) in Iraq are designed as conventional plants. This treatment process does not significantly affect the concentrations of the dissolved constituents, so the characteristics of the raw and treated water are quite the same. There are eight water treatment plants (WTPs) from the north to the south of Baghdad city, Al-Karkh, East Tigris, Al-Wathbah, Al-Karamah, Al-Qadisiya, Al-Dawrah, Al-Rashid, Al-Wahda WTPs (Figure 1). The data used in this study were sampled, tested and applied from Baghdad Mayoralty (Amanat

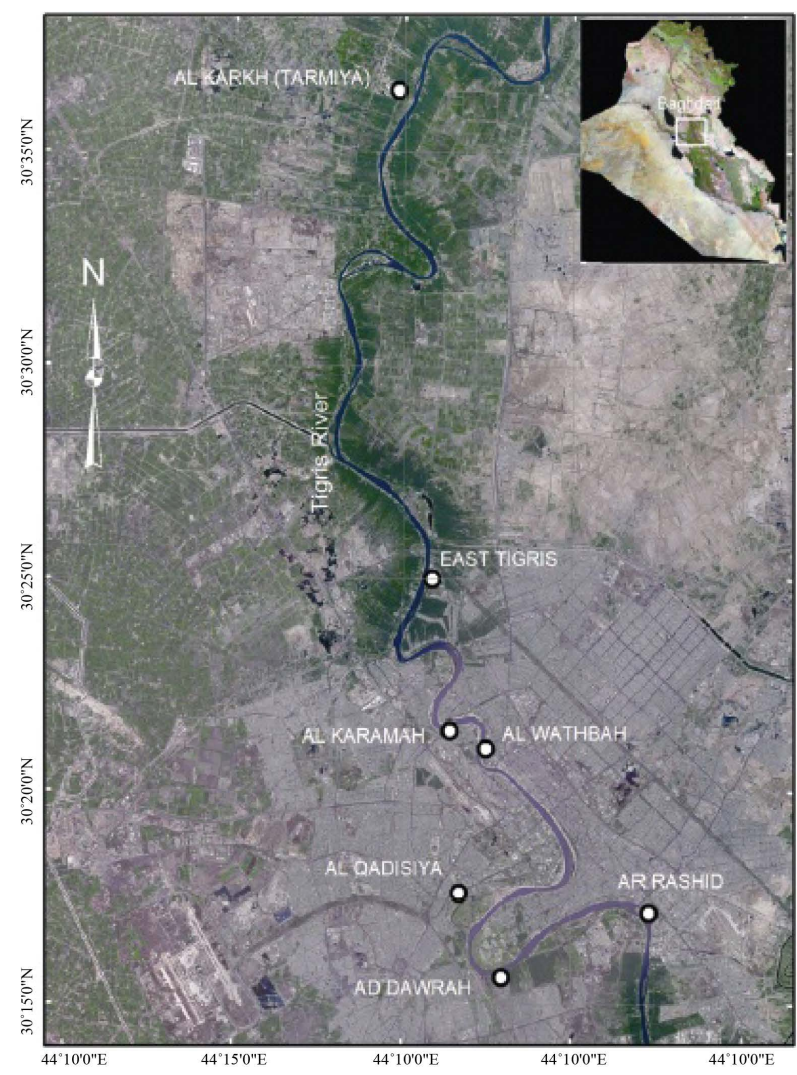

Figure 1. Sampling locations across Tigris River, within Baghdad City. Location of water treatment plant. 
Baghdad)-Water office which represents the quality of the treated water from the WTPs in Baghdad city according to WHO standards recorded for the period between 2000 until 2013. In order to evaluate the chemical stability of any type of water, many parameters are detected, such as Temperature, Alkalinity $\mathrm{mg} / \mathrm{l}$ as $\mathrm{CaCO}_{3}$, $\mathrm{pH}$, Total dissolved Solids (TDS), and concentration of Calcium (Ca). The variation in water stability with time and distance from the north to the south of Baghdad is to be indicated.

\subsection{Calculations of the Water Stability Indices}

\subsubsection{Langelier Saturation Index}

Work by professor W. F. Langelier, published in 1936 deals with the conditions at which water is in equilibrium with calcium carbonate. An equation developed by Langelier makes it possible to predict the tendency of calcium carbonate either to precipitate or to dissolve under varying conditions. Langelier Saturation Index (LSI) is an equilibrium model derived from the theoretical concept of saturation and provides an indicator of the degree of saturation of water with respect to calcium carbonate and can calculate from [14]:

$$
\mathrm{LSI}=\mathrm{pH} a-\mathrm{pHs}
$$

where:

$\mathrm{pH} a$ : the measured water $\mathrm{pH}$.

$\mathrm{pHs}$ : the $\mathrm{pH}$ at which water with a given calcium content and alkalinity is in equilibrium with calcium carbonate.

The equation expresses the relationship of: $\mathrm{pH}$, calcium, total alkalinity, dissolved solids, and temperature as they are related to the solubility of calcium carbonate in waters with $\mathrm{pH}$ of 6.5 to 9.5. This is known as the $\mathrm{pHs:}$

$$
\mathrm{pHs}=(9.3+A+B)-(C+D)
$$

where:

$$
\begin{gathered}
A=\frac{\left[\log _{10}(\mathrm{TDS})-1\right]}{10} \\
B=-13.12 \times \log _{10}\left({ }^{\circ} \mathrm{C}+273\right)+34.55 \\
C=\log _{10}\left(\mathrm{Ca}^{+2} \text { as } \mathrm{CaCO}_{3}\right)-0.4 \\
D=\log _{10}\left[\text { Alkalinityas } \mathrm{CaCO}_{3}\right]
\end{gathered}
$$

\subsubsection{Ryznar Stability Index (RSI)}

The Ryznar index is an empirical method for predicting scaling tendencies of water based on study of operating results with water at various saturation indices. The Stability Index developed by John Ryzner in 1944 used the Langelier Index (LSI) as a component in a new formula to improve the accuracy in predicting the scaling or corrosion tendencies of water [14].

The Ryznar index (RSI) takes the form:

$$
(\mathrm{RSI})=2(\mathrm{pHs})-\mathrm{pH}=\mathrm{pH} s-\mathrm{LSI}
$$

The criteria used to give an indication of the stability indices can be summarized in Table 1.

\section{Results and Discussion}

\subsection{Treated Water Quality}

Water quality parameters from Baghdad's WTPs compared with Iraqi and WHO drinking water standards are shown in Table 2, where the treated water is within these standards. In order to reach a better view on the variation of the treated water quality from the WTPs and how they may affect water stability, selected results from the determination of water quality parameters are discussed below.

Alkalinity in water is due to the presence of weak acid systems that consume hydrogen ions produced by other reactions or produce hydrogen ions when they are needed by other reactions allowing chemical or biological 
Table 1. Summary of water stability indices [18].

\begin{tabular}{|c|c|}
\hline Index value & Water condition \\
\hline LSI $>0$ & $\begin{array}{l}\text { Water is supersaturated with respect to calcium carbonate }\left(\mathrm{CaCO}_{3}\right) \text { and scale forming and } \mathrm{CaCO}_{3} \text { precipitation may } \\
\text { occur. }\end{array}$ \\
\hline LSI $=0$ & $\begin{array}{l}\text { Water is considered to be neutral. Neither scale-forming nor scale removing. Saturated, } \mathrm{CaCO}_{3} \text { is in equilibrium. } \\
\text { Borderline scale potential. }\end{array}$ \\
\hline LSI $<0$ & $\begin{array}{l}\text { Water is under saturated with respect to calcium carbonate. Under saturated water has a tendency to remove existing } \\
\text { calcium carbonate protective coatings in pipelines and equipment. No potential to scale, the water will dissolve } \\
\mathrm{CaCO}_{3} \text {. }\end{array}$ \\
\hline $\mathrm{RSI} \leq 6$ & Supersaturated, tend to precipitate $\mathrm{CaCO}_{3}$. The scale tendency increase as the index decrease. \\
\hline $6<\mathrm{RSI}<7$ & $\begin{array}{l}\text { Saturated, } \mathrm{CaCO}_{3} \text { is in equilibrium. The calcium carbonate formation probably does not lead to a protective corrosion } \\
\text { inhibitor film. }\end{array}$ \\
\hline LSI $\geq 7$ & Under saturated, tend to dissolved $\mathrm{CaCO}_{3}$. Mild steel corrosion becomes an increasing problem. \\
\hline
\end{tabular}

Table 2. Statistical summary of Baghdad's WTPs-treated water quality data.

\begin{tabular}{|c|c|c|c|c|c|}
\hline \multirow{2}{*}{ Parameter } & \multirow{2}{*}{ Min. } & \multirow{2}{*}{ Max. } & \multirow{2}{*}{ Average } & \multicolumn{2}{|c|}{ Drinking standards } \\
\hline & & & & WHO & Iraqi \\
\hline Temperature $\left({ }^{\circ} \mathrm{C}\right)$ & 21 & 22.81 & 21.89 & - & - \\
\hline Alkalinity as $\mathrm{CaCO}_{3}(\mathrm{mg} / \mathrm{L})$ & 124.08 & 143 & 137.77 & $30-500$ & $125-200$ \\
\hline Calcium as $\mathrm{Ca}(\mathrm{mg} / \mathrm{L})$ & 70 & 120.75 & 83.46 & 75 & 75 \\
\hline $\mathrm{pH}$ & 7.45 & 7.90 & 7.63 & $7-8.5$ & $6.5-8.5$ \\
\hline Total dissolved Solids TDS (mg/L) & 410 & 696.5 & 541.53 & 500 & 1000 \\
\hline
\end{tabular}

activities to take place within water without changing the $\mathrm{pH}$ [15]. The primary source of alkalinity is the carbonate system, although phosphates, silicates, borates, carboxylates, and other weak acid systems can also contribute. In water treatment plants, alkalinity is required in the coagulation process for the reaction of alum; lime could be added if the natural alkalinity is not enough for this reaction [8]. From the recorded data the variation in alkalinity ranged between 124.08 to $143 \mathrm{mg} / \mathrm{L}$ with average $137.77 \mathrm{mg} / \mathrm{L}$ as $\mathrm{CaCO}_{3}$ as shown in Table 2. Corrosivity of water decreases as the alkalinity increases where it is necessary to provide a stable $\mathrm{pH}$ throughout the distribution system for corrosion control of metal pipes [16]. Low iron corrosion rates and iron concentrations in the distribution systems have been associated with higher alkalinities [11].

Calcium is the second most prevalent constituent in most surface waters and is generally among the most prevalent three or four ions in groundwater. Weathering and soil ion exchange reactions are the main sources of calcium in natural waters [8]. Increasing the Ca concentration will decrease the corrosivity of water, as $\mathrm{Ca}$ is important in various roles, including calcium carbonate scales, mixed iron/calcium carbonate solids and the formation of a passivating film on the surface of the pipe, to control corrosion [16]. From the recorded data the concentration of Ca ranged between 70 to $120.75 \mathrm{mg} / \mathrm{L}$ with an average of $83.46 \mathrm{mg} / \mathrm{L}$ in all WTPs as shown in Table 2.

$\mathrm{pH}$ is important in water treatment as it directly influences the dosages of chemicals added to reduce hardness and coagulate particles [8]. High $\mathrm{pH}$ of the water flowing in the distribution system will decrease the solubility of the corrosion by products formed in the system [16]. The results of $\mathrm{pH}$ varied from 7.45 to 7.90 with average 7.63, indicating that the water is almost neutral to sub-alkaline in nature.

Total dissolved solids (TDS) in water are due to inorganic salts. Principally these inorganic constituents are calcium, magnesium, sodium, and potassium salts of bicarbonate, chloride, sulfate, nitrate and phosphate. These compounds originate from weathering and leaching of rocks, soils and sediments. Also some of these compounds are added to the water in the treatment plants [8]. From the recorded data the variation concentration of TDS ranged between 410 to $696.5 \mathrm{mg} / \mathrm{L}$ with an average of $541.53 \mathrm{mg} / \mathrm{L}$ as shown in Table 2 . The conventional treatment process does not affect the dissolved content of the treated water so the high TDS concentrations in the effluent are due to the raw water quality entering these plants. The increasing amounts of dissolved solids in the Tigris River are due to the discharge of waste water, leaching of fertilizers and the natural weathering of the soil. The effect of TDS content on water corrosivity is a complex issue. Some species such as carbonate and bi- 
carbonate reduce corrosion, whereas chloride, sulfate, bromide and nitrate ions markedly accelerate corrosion [5].

Temperature also affects the corrosion process. Higher water temperatures accelerate the rate of corrosion by increasing the rate of the cathodic reaction. The chemical reaction rate generally is doubled for every $8^{\circ} \mathrm{C}$ increase in temperature [17] [18].

\subsection{Langelier vs Ryzner Stability Indices}

The stability of the treated water from all WTPs in Baghdad was calculated according to the water quality of the effluents of these plants. The US Environmental Protection Agency (USEPA) has recommended the use of Langelier (LSI) and Ryznar (RSI) stability indexes by utilities to monitor the corrosion potential of water [10]. Table 3 shows that the correlation coefficient between LSI and the water quality parameters, it is observed that $\mathrm{pH}$ had the highest significant relationship with $\mathrm{R}=0.507$ at $(P<0.01)$ and then temperature $(\mathrm{R}=0.421)$ while the other parameters had a weak relationship. Temperature had the highest significant relationship with $\mathrm{RSI}(\mathrm{R}=$ 0.468 ) as shown in Table 4, while alkalinity and $\mathrm{pH}$ came second with $\mathrm{R}=0.306$ and $\mathrm{R}=0.311$ respectively.

Table 5 shows the stability indices LSI and RSI of the effluents from Baghdad's WTPs. The average annual LSI results are classified as positive values in East Tigris, Al-Wathbah, Al-Karamah, Al-Qadisiya, and Al-Rashid WTPs which refer to water is supersaturated with respect to calcium carbonate $\left(\mathrm{CaCO}_{3}\right)$ where scale forming of $\mathrm{CaCO}_{3}$ precipitation may occur. But negative values were calculated at Al-Karkh, Al-Dawrah, and AlWahda WTPs which refer that the water is under saturated with respect to calcium carbonate. Under saturated water has the tendency to remove existing calcium carbonate protective coatings in pipelines and equipment. While average annual RSI results in all WTPs can be classified more than 7 and ranged between 7.344 to7.785 which refers to under saturated, or classified corrosive water as indicated in Table 1.

\subsection{Annual LSI \& RSI}

The annual LSI and RSI for the period 2000-2013; are shown in Table 6. LSI results show that, for treated water

Table 3. Correlation coefficient between LSI and treated water quality parameters.

\begin{tabular}{ccccccc}
\hline & LSI & Temp & Alkalinity & Ca & pH & TDS \\
\hline LSI & 1 & & & & \\
Temp & $0.424\left(^{* *}\right)$ & 1 & & & \\
Alkalinity & $-0.221\left(^{*}\right)$ & -0.163 & 1 & 1 & & \\
Ca & $0.286\left(^{* *}\right)$ & -0.119 & $-0.553\left(^{* *}\right)$ & $0.198\left(^{*}\right)$ & 1 & 1 \\
pH & $0.507\left(^{* *}\right)$ & $0.381\left(^{* *}\right)$ & $0.227\left(^{* *}\right.$ & $0.925\left(^{* *}\right)$ & 0.129 & \\
TDS & 0.120 & $-0.235\left(^{* *}\right)$ & $-0.447\left(^{* *}\right)$ & & & \\
\hline
\end{tabular}

${ }^{* *}$ Correlation is significant at the 0.01 level (2-tailed). ${ }^{*}$ Correlation is significant at the 0.05 level (2-tailed).

Table 4. Correlation coefficient between RSI and treated water quality parameters.

\begin{tabular}{ccccccc}
\hline & RSI & Temp & Alkalinity & Ca & pH & TDS \\
\hline RSI & 1 & & & & & \\
Temp & $-0.468\left(^{* *}\right)$ & 1 & & & \\
Alkalinity & $0.306\left(^{* *}\right)$ & -0.163 & 1 & & & \\
Ca & $-0.280\left(^{* *}\right)$ & -0.119 & $-0.553\left(^{* *}\right)$ & 1 & & 1 \\
pH & $-0.311\left(^{* *}\right)$ & $0.381\left(^{* *}\right)$ & $0.227\left(^{*}\right)$ & $0.198\left(^{*}\right)$ & 0.129 & 1 \\
TDS & -0.127 & $-0.235\left(^{* *}\right)$ & $-0.447\left(^{* *}\right)$ & $0.925\left(^{* *}\right)$ & 0.129
\end{tabular}

${ }^{* *}$ Correlation is significant at the 0.01 level (2-tailed). ${ }^{*}$ Correlation is significant at the 0.05 level (2-tailed).

Table 5. Annual LSI and RSI of effluent water from WTPs from 2000-2013.

\begin{tabular}{cccccccccc}
\hline Year & Al-Karkh & East Tigris & Al-Wathbah & Al-Karamah & Al-Qadisiya & Al-Dawrah & Al-Rashid & Al-Wahda \\
\hline LSI & -0.122 & 0.032 & 0.042 & 0.195 & 0.168 & -0.006 & 0.045 & -0.012 \\
RSI & 7.785 & 7.595 & 7.505 & 7.344 & 7.338 & 7.540 & 7.473 \\
\hline
\end{tabular}


Table 6. Annual LSI and RSI of effluent water from WTPs from 2000-2013.

\begin{tabular}{lllllllllllllll}
\hline Year & 2000 & 2001 & 2002 & 2003 & 2004 & 2005 & 2006 & 2007 & 2008 & 2009 & 2010 & 2011 & 2012 & 2013 \\
\hline LSI & 0.156 & 0.074 & 0.067 & 0.081 & 0.002 & 0.147 & 0.071 & 0.370 & 0.120 & -0.082 & -0.136 & -0.065 & 0.021 & 0.002 \\
RSI & 7.38 & 7.54 & 7.5 & 7.53 & 7.59 & 7.40 & 7.52 & 7.17 & 7.34 & 7.66 & 7.68 & 7.63 & 7.54 & 7.58 \\
\hline
\end{tabular}

from year 2000-2008 and 2012-2013 are positive values indicating scale forming water while from 2009-2011 are negative values or corrosive water. While RSI results from period 2000-2013 show more than 7 as under saturated, tend to dissolved $\mathrm{CaCO}_{3}$ or corrosive water.

The differences between LSI and RSI shown in Table 5 and Table 6 (indicating corrosive or scale forming) can be according to: LSI measures only the directional tendency or driving force for $\mathrm{CaCO}_{3}$ to precipitate or dissolve. It cannot be used as a quantitative measure, as two different waters one with low hardness (corrosive) and the other of high hardness (scale forming) can have the same LSI. While RSI makes it possible to distinguish between the two types, as RSI is based on the actual operating results with waters having various saturation indices [14] so it is more reliable.

\section{Conclusions}

As the choice of any index may propose different description water stability, so selecting the most appropriate index conforming to the actual situation of any system is the most sophisticated stage in making predictions. According to the present study:

1) The treated water from the WTPs in Baghdad is considered corrosive. So these plants need to pay attention to achieve national water quality standards and reduce corrosion and corrosion by-products, with corrective action that should be made to prevent corrosion in water supply networks.

2) Water quality affects the corrositivity of the treated water flowing from the WTPs into the distribution system in Baghdad city.

3) The calculated stability indices LSI and RSI indicated that the treated water from the plants was corrosive.

4) Using LSI together with the RSI contributes to more accurate prediction of the scaling or corrosive tendencies of water.

\section{Recommendations}

Control of water quality in the distribution system seeks to preserve the basic characteristics of water during its conveyance from the point of production and treatment to the consumers tap. The finished water from the treatment plants should be completely stable in its compositional and physical attributes. Several methods could be applied in the treatment plants to produce stable water like $\mathrm{pH}$ adjustment or adding corrosion inhibitors.

\section{Acknowledgements}

Our special gratitude and many thanks are forwarded to "Baghdad Mayoralty-Water Office” for supplying the data and without their support and encouragement the work would have not been done.

\section{References}

[1] Qasim, S.R., Edward, M.M. and Guany, Z. (2000) Planning, Design, and Operation. Prentice Hall PTR. Upper Saddle River, NJ07458.

[2] AWWA (1971) Water Quality and Treatment. 3rd Edition, McGraw Hill Book Company, New York.

[3] Australian Drinking Water Guidelines (1996) National Water Quality Management Strategy. NHMRC and ARMCANZ, Canberra.

[4] Imran, S.A., Dietz, J.D., Mutoti, G., Taylor, J.S., Randall, A.A. and Cooper, A.C.D. (2005) Red Water Release in Drinking Water Distribution System. American Water Works Association, 97, 93-100.

[5] Fang, W. (2004) The Research on Water Chemical Stabilization and Control Methods in the Urban Water Supply System. Hunan University, Changsha.

[6] Salvato, J.A., Dee, P.E., Nemerow, N.L. and Agardy, F.J. (2003) Environmental Engineering. John Wiley \& Sons, Inc., Hoboken. 
[7] Rossum, J.R. and Merrill, D.T. (1983) An Evaluation of the Calcium Carbonate Saturation Indexes. Journal of American Water Works Association, 75, 95-100.

[8] MWH (2005) Water Treatment Principles and Design. 2nd Edition, John Wiley \& Sons, Inc., Hoboken.

[9] Millette, J.R., Hammonds, A.F., Pansing, M.F., Hansen, E.C. and Clark, P.J. (1980) Aggressive Water: Assessing the Extent of the Problem. American Water Works Association, 72, 262-266.

[10] Pisigan Jr., R.A. and Singley, J.E. (1985) Effects of Quality Parameters on the Corrosion of Galvanized Steel. American Water Works Association, 77, 76-82.

[11] Pisigan Jr., R.A. and Singley, J.E. (1987) Influence of Buffer Capacity, Chlorine Residual and Flow Rate on Corrosion of Mild Steel and Copper. American Water Works Association, 79, 62-70.

[12] Reiber, S.H., Ferguson, J.F. and Benjamin, M.M. (1987) Corrosion Monitoring and Control in the Pacific Northwest. American Water Works Association, 79, 71-74.

[13] Al-Adili, A.S. (1998) Geotechnical Evaluation of Baghdad Soil Subsidence and Their Treatments. Ph.D. Thesis, University of Baghdad, Baghdad.

[14] Water Service LTD (2004) Indexes for Calcium Carbonate. export@power-chemicals.com

[15] Gebbie, P. (2000) Water Stability: What Does It Mean and How Do You Measure It? Proceedings of the 63th Annual Water Industry Engineers and Operators Conference, Warrnambool, 6-7 September 2000, 50-58.

[16] Schock, M.R. (1989) Understanding Corrosion Control Strategies for Lead. American Water Works Association, 81, 88-100.

[17] Kawamura, S. (2000) Integrated Design and Operation of Water Treatment Facilities. 2nd Edition, John Wiley \& Sons, Inc., New York.

[18] Hadi, M. (2010) Development Software for Calculation of Eight Important Water Corrosion Indices. Proceedings of the 12th National Conference on Environmental Health, Tehran. 
Scientific Research Publishing (SCIRP) is one of the largest Open Access journal publishers. It is currently publishing more than 200 open access, online, peer-reviewed journals covering a wide range of academic disciplines. SCIRP serves the worldwide academic communities and contributes to the progress and application of science with its publication.

Other selected journals from SCIRP are listed as below. Submit your manuscript to us via either submit@scirp.org or Online Submission Portal.
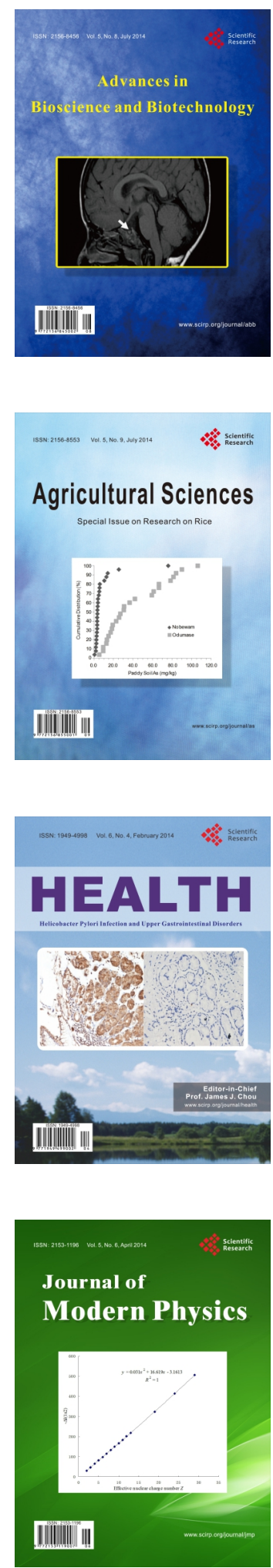
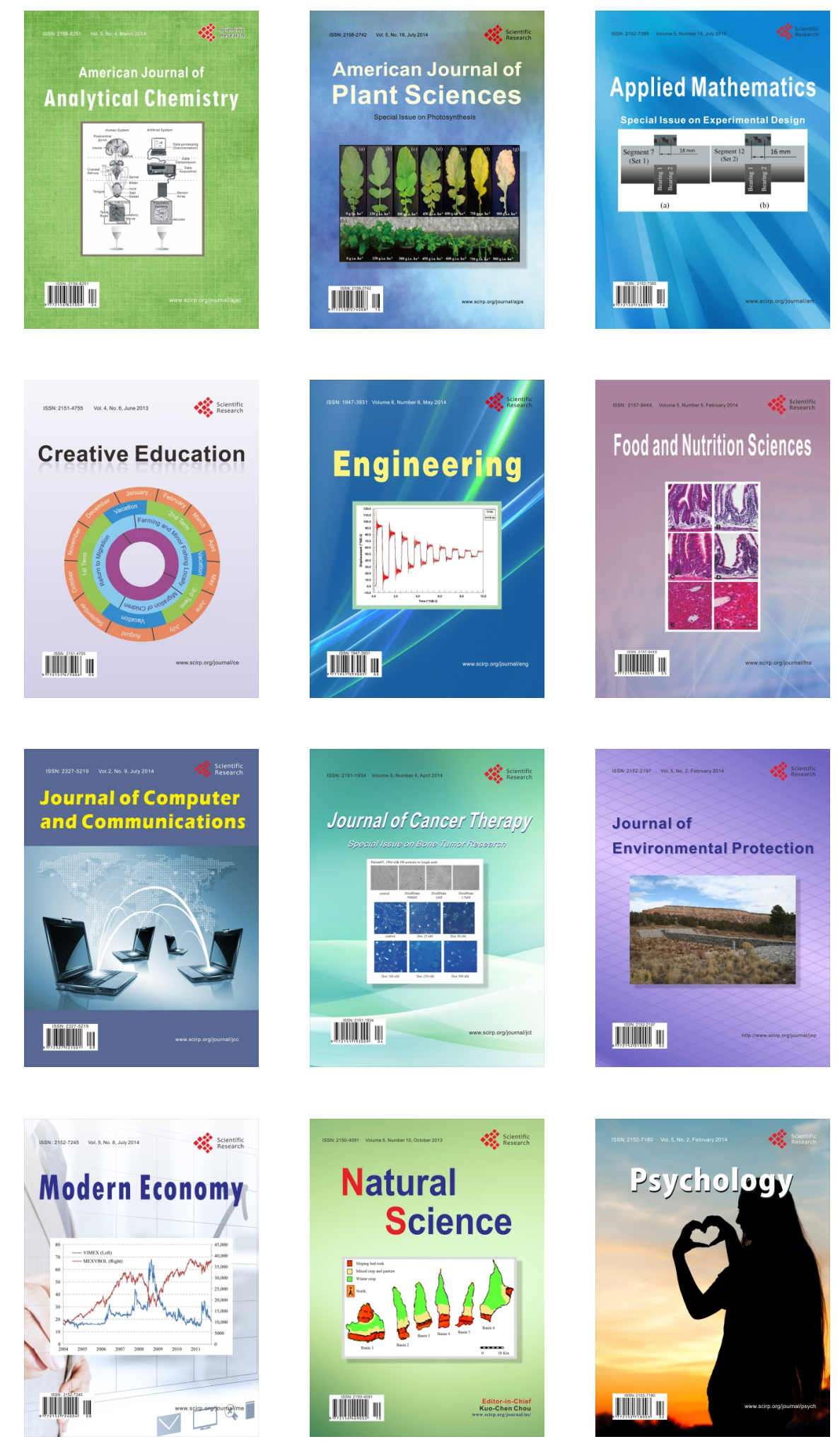